\title{
Impact of Human Resource Management Practices on Employee Performance in Banking Industry (A Case Study on the Head Office of Three Private Banks in Yangon)
}

\author{
Khin Ohnmar Pa Pa Naing*11, Than Than Win ${ }^{1}$, Su Yi Maw ${ }^{2}$ \\ ${ }^{1}$ Department of Commerce, Yangon University of Economics \\ ${ }^{2}$ Department of Human Resources, Ayeyarwady Bank \\ *Corresponding author: khinohnmar230@gmail.com
}

\begin{abstract}
The importance of HRM has grown manifold in the banking industry as its nature is mainly service oriented. The objectives of the study are to describe HRM practices of private banks and to analyze the impact of HRM practices on employees' performance. Descriptive and Inferential analysis were used in this study. A sample of 150 staff is randomly selected from three private banks namely AYA, KBZ, and CB. The secondary data was collected from previous literatures, textbooks, and websites. The study found that training and development are significantly related to employee's performance. Therefore, this study results suggests that banks should strive to attract talent, well trained and enthusiastic employees will improve their performance. Thus, successful and effective implementation of training programs would empower bank's employees and improves their performance. Thus, the bank management team should implement the success and effective training programs in order to increase the efficiency of bank performance. To improve training program, top management needs to create 5-steps effective training programs such as assess training needs and set organizational training. Thus, best practices of HRM stimulate bank staffs' performance which in turn improves HRM practices.
\end{abstract}

Keywords: Bank staffs, Employees Performance, HRMPs, Training and Development Program, Private Banks

\section{Introduction}

Today, employees are recognized as the main assets in any organizations. Therefore, employees could be a competitive advantage if their organization provides more attention and invest in developing employee' skills at the workplace (Danish \& Usman, 2010). Human resource plays a dual role in an organization as factor of production and other operative elements. Organization like banks need to nature their human resources in an efficient manner in order to achieve good profitability. Human resources management (HRM) is a term used to represent part of an organization's activities concerned with the recruitment, development, and management of its employees (Wood \& Wall, 2002). The modern field of HRM is attracting a great deal of attention because of its potential impact on organization's survival and prosperity. These innovative HRM practices are required to be implemented in the organizations in order to attract, retain, and add value to the work force. Best HRM practices only can ensure continued success of business organization. Zulfqar, Wahid, Farooq, Maqbool, and Arfan (2012) conducted a study to scrutinize the relationship and nature of relationship between the employees' perceived performance and 
Borneo Journal of Social Science \& Humanities

DOI: https://doi.org/10.35370/bjssh.2021.3.1-04

e-ISSN:2682-8235

(C) 2018, UCTS Publisher.

Submitted: 16 May 2021

Accepted: 24 June 2021

Published: 30 June 2021

HRM practices in the banking sector of Pakistan. The findings of the study found that, the employee perceived performance and HRM practices has the positive and significant related. Alternatively some study (Deb, 2006) showed that the way HRM practices provide an edge to employee's commitment. This study found that organization commitment are significantly affected by HRM practices such as training and development, compensation, and welfare activities which are associated with superior organizational performance.

Myanmar is in the early stages of financial reforms which the government has made an economic priority. Modern banking and financial services in Myanmar are in their infancy stage. The banking sector comprises the Central Bank of Myanmar (CBM) which was established pursuant to the Central Bank of Myanmar law in 1990, four other state-owned banks, and 19 domestic banks. Banking industries are going through a series of rapid changes because of the technological development. Under the market economic system, banking industry is highly competitive. Banks in Myanmar that encounter such stiff pressure intend to win victoriously over their clients, yet it isn't as simple as one could imagine of. To achieve organizational goals whereby maximizing the value as well minimizing the cost within the organization, skillful staffs are required and this will only possible if the firms apply effective and efficient human resource practices. This paper does not represent the whole banking sector but the finding of this study somehow helpful to the banking sector in their effort to improve the employees' performance. To improve employee performance, one needs to understand what they value the most. It explores the relationship between HR practices and employee performance, and further identifies the element of HR practices which strongly influence the employees' performance. The result from this study may assist in the development of an effective human resources management performance program for the organizations. This study will be helpful for banking industry, to improve the performance of employees through implementing of HRM practices and to optimize the abilities of the employees in their day-to-day work. The aims of this study are outlined as follows:

i. To describe the HRM practices and employee performance of private banks at Yangon; and

ii. To analyze the effect of HRM practices on employees performance.

\section{Literature Review}

HRM is concerned with the human beings in an organization. The management of man is a very important and challenging job because of the dynamic nature of the people. People are unique in their mental abilities, tacticians, sentiments, and behaviors. They differ widely also as a group and are subjected to various influences. People are responsive, they feel, think, and act therefore they cannot be operated like a machine or shifted, and altered like template in a room layout. Therefore, they need a tactful handling by management personnel (Ganesan, 2014). HRM is the process of managing people of an organization with a human approach. Effective HR approach enables the managers to view the people as an important resource. It is the approach through which organization can use the employees for the advantages of the organization as well as for the growth, development, and self-satisfaction of the employees. Thus, HRM is a system that focuses on human resources development, and effective management of people will make the employees feel being appreciated in their employment.

HRMPs are essential for an ideal integration of firms' success in the global business environment. The challenges and trends of HRMPs have been revolutionized over the years. Thus, 
Borneo Journal of Social Science \& Humanities

DOI: https://doi.org/10.35370/bjssh.2021.3.1-04

e-ISSN:2682-8235

(C) 2018, UCTS Publisher.

Submitted: 16 May 2021

Accepted: 24 June 2021

Published: 30 June 2021

HRMPs is vital for successful implementation of HR policies effectively and efficiently to achieve the organization's goals (Mathis \& Jackson, 2008). Likewise, practices of HRM are valuable for the organization to take practical measures for improving the efficiency of the workers and enhancing their commitment (Deb, 2006). Moreover, implementing HRMPs effectively leads to attracting, motivating, and retaining employees in order to enhance individual and organizational performance (Pablos \& Lytras, 2008). After reviewing the previous studies which have discussed the concept of HR practices and its relationship with explanatory variables in the organization, the researchers concluded that HR practices and the factors which affect HRMPs are differed across firms and countries.

\section{Recruitment and Selection}

Boudreau and Rynes (1985) defined recruiting as "activities or practices that define the characteristics of applicants to whom selection procedures are ultimately applied". Organization needs to select the policy of recruitment wisely because it's reflecting the overall strategy of the organization. Organization's policy and the vision can be considered as an indicator to the efforts of the recruitment and it is an example of the internal factors (Nel, Werner, Du Plesis, Fazey, Erwee, Pillay, Mckinnon, Millett, \& Wordsworth, 2012). As a skilled and professional HR manager, it is vital to have the competency and ability to select appropriate employees and place them in suitable work positions. Selection is an important element of HR practices, as the employee selection is closely related and connected with the growth of the organization. Selection is collecting the information about the applicants to decide who is fit and should be employed each work position (Shen \& Edwards, 2004).

\section{Training and Development}

Training and Development is an organization's subsystem that emphasizes on the enhancement of the individuals and groups' performance. Training is an instructional process that includes the sharpening skills, principles, changing attitudes, and acquiring more knowledge and information to increase the employee performance. Training can be described as an effort to develop additional skills needed today or in future to enhance the performance level of the employee (Jackson \& Schuler, 2000). To improve organizational performance, training can be used as a tool to increase efficiency and effectiveness of employees (Cook \& Hunsaker, 2001). Moreover, extensive training programs are conducted by employees to improve the performance of employee in order to achieve strategic position over competitors (Brown, Treviño, \& Harrison, 2005).

\section{Performance Appraisal}

Performance appraisal refers to observing and evaluating the performance of the employee, recording the assessment, and providing the employee with feedback. Skillful managers give feedback and support on the appropriate elements of the employee's success, during performance evaluation. They also describe performance areas that need improvement. One way to review the performance and potential of staff is through a system called performance appraisal. This is a vital personnel role and human resource management practice. There are several potential benefits to both the individual and the organization. Nevertheless, it is crucial that the values and ethics of performance appraisal and the issues to be answered are given careful and thorough consideration. In order to establish an effective appraisal program, careful attention must be paid to several 
Borneo Journal of Social Science \& Humanities

DOI: https://doi.org/10.35370/bjssh.2021.3.1-04

e-ISSN:2682-8235

(C) 2018, UCTS Publisher.

Submitted: 16 May 2021

Accepted: 24 June 2021

Published: 30 June 2021

important factors relevant to its adoption and implementation, to the various assessment approaches, and potential problem areas.

\section{Compensation and Reward System}

Employee compensation covers all aspects of pay to and from employees. It has two major components, direct financial compensation (salaries, wages, benefits, commissions, and bonuses) and indirect financial payments (such as employer-paid insurance and holidays). There are two simple ways of making direct payments to employees: time-based pay or performance-based rewards. Time-based scheduling is the cornerstone of compensation policies for most employers.

\section{Employee Performance}

Employee performance is one of the most factors that effects on the performance of the organization. The successful organization understands the importance of HR as a critical factor directly affects and contributes on the performance (AL-Qudah, Al-Jaber, Zarga, \& Orabi, 2014). Any organization's success depends on the actions and behavior of its employees, although there are many other factors that might contribute to that success, such as the size of the organization, the environment in which it operates and its activities. Human resource management practices are often used to evaluate the employee's performance in the organization, and in the modern age and highly competitive organizational environment between the organizations, the trend to enhance employee performance is by improve HRM practices (Bowra, Sharif, Saeed, \& Niazi, 2012).

\section{Maslow's Hierachy of Needs Theory}

Abraham Maslow theorized that people are motivated by five types of needs, which he ranked into a hierarchy. Each individual's current situation dictates which level of need is the most critical for them at any specific point in time. How an employer meets these needs changes with each level and contributes toward employee job satisfaction, resulting in lower turnover and higher employee retention rates. Five levels of Maslow's hierarchy of needs are survival, safety, belonging, selfesteem, and self-actualized.

Depending on the employee's situation, they could be at the bottom of the hierarchy at the survival level-sometimes referred to as physiological or at the top at self-actualization. Maslow believed, like many managers today that before incentives designed to provide a sense of belonging, self-esteem or opportunity for growth as part of self-actualization can be effective, employees must feel that their needs for survival and security are being met.

\section{Relationship between HRM practices and Employee Performance}

Recruitment and selection are one of the most important HRMPs. It is a process of finding, assessing, and having the right people in the right job. A positive relationship has been reported among recruitment, selection, and other procedures that are used for selection of the applicants effectively which have a significant effect on the firms' profits (Hausdorf \& Duncan, 2004). In addition, it is the process of searching the applicants for employment and encouraging potential candidates to apply for jobs (Jain \& Saakshi, 2005).

Training and development activities allow organizations to adjust, be a competitor, advanced skills, innovate, develop, enhance employees safety, expand service, and reach firm's goals (Salas, Tannenbaum, Kraiger, \& Smith-Jentsch, 2012). Consequently, any organization 
strives to compete in the global economy, differentiation on the basis of the skills, knowledge, and motivation of their workforce must realize the importance of training and development and its impact on employees and organizational performance (Aguinis \& Kraiger, 2009).

Compensation and Incentives are the most important in HRMPs. Compensation refers to consideration that is paid to an individual who is working for the organization. Compensation for internal employees is managed by compensation system of the organization which in turn plays an important role in fostering employees' performance and increases their productivity (Kramer \& Briffault, 1991).

Carlson, Upton, \& Seaman (2006) investigated the financial and non-financial rewards in family business SMEs. They found at each level in the firm, accomplishment of sales-growth used more financial rewards. According to the Cumming (1993) pointed out that a performance appraisal is an approach to assessing the employee's work performance in a measurable way. The objective of this assessment is to improve the efficiency of an enterprise by attempting to mobilize the best possible efforts from individuals employed in it. The primary objective of a performance appraisal is to ensure the maximum utilization of every employee's skills, knowledge, and interests (Arthur, 2008). Another study conducted by Soomro et al. (2011) revealed that HRMPs were correlated positively with the employee performance.

\section{Previous Studied of the Study}

According to the previous studies, HRMPs have been applied widely by researchers in diverse industry and organizations to assess employee performance of human resource practices tools. HR practices such as recruitment and selection, training and development, performance appraisal, and compensation and rewards has been measured in a diversity of service industries especially banking industry. AL-Qudah, Osman, \& Al-Qudah (2014) presented the Effect of HRM Practices on Employee Performance in Malaysian Skills Institute (MSI). In his research framework, two HRM practices are applied which are recruitment and selection and compensation (Dependent variables) and Employee performance (Independent variable). Moreover, it investigated the factors that effect on recruitment and selection, compensation toward employee performance in MSI. Selected sample size is 60 and the study population, which consisted of employees in the MSI, comprised of 56 respondents. The researcher created and distributed a questionnaire in order to achieve the study goals and collected and analyzed the data using SPSS. The conceptual framework of the study is shown in following Figure 1.

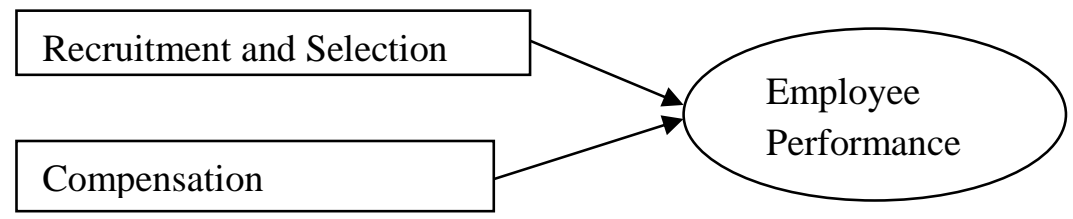

Figure 1: Effect of Human Resources Management Practices on Employee Performance Source: AL-Qudah et al. (2014)

According to the above conceptual framework, the results indicated that recruitment and selection and compensation significantly correlated with the employee performance in MSI. 
Moreover, Athar, Umair, Muhammad Fahad, Hafiz, Imtiaz, Waqas, Muhammad, \& Rizwan (2014) examined HR practices effect on employee performance of banking sector of Pakistan. The questionnaires were sent to 150 employees of different banks in Lahore. The study finds that the employee performance is positively correlated with the reward, recruitment and selection and training. Thus, the reward, recruitment and selection, and training are strong performance predictors.

Hassan (2016) conducted to determine the impact of HRM practices on employee's performance in the Textile industry of Pakistan. Random sampling technique was used to collect data for this research study. In his conceptual framework, it comprises of dependent variables of HR practices which are compensation, career planning, performance appraisal, training and employee involvement. A questionnaire based on 34 items which was distributed among 68 employees of textile industry for data collection. Person's statistical correlation methodology and regression analysis were applied to the data to test the relationship between HRM practices and performance of the employees. The results show that HRM practices including Compensation, Career Planning, Performance Appraisal, Training, and Employee Involvement have a significant impact on performance of employees. Hence, it is proved that independent variables contribute positively towards change in the dependent variable. The conceptual framework is shown in following figure.

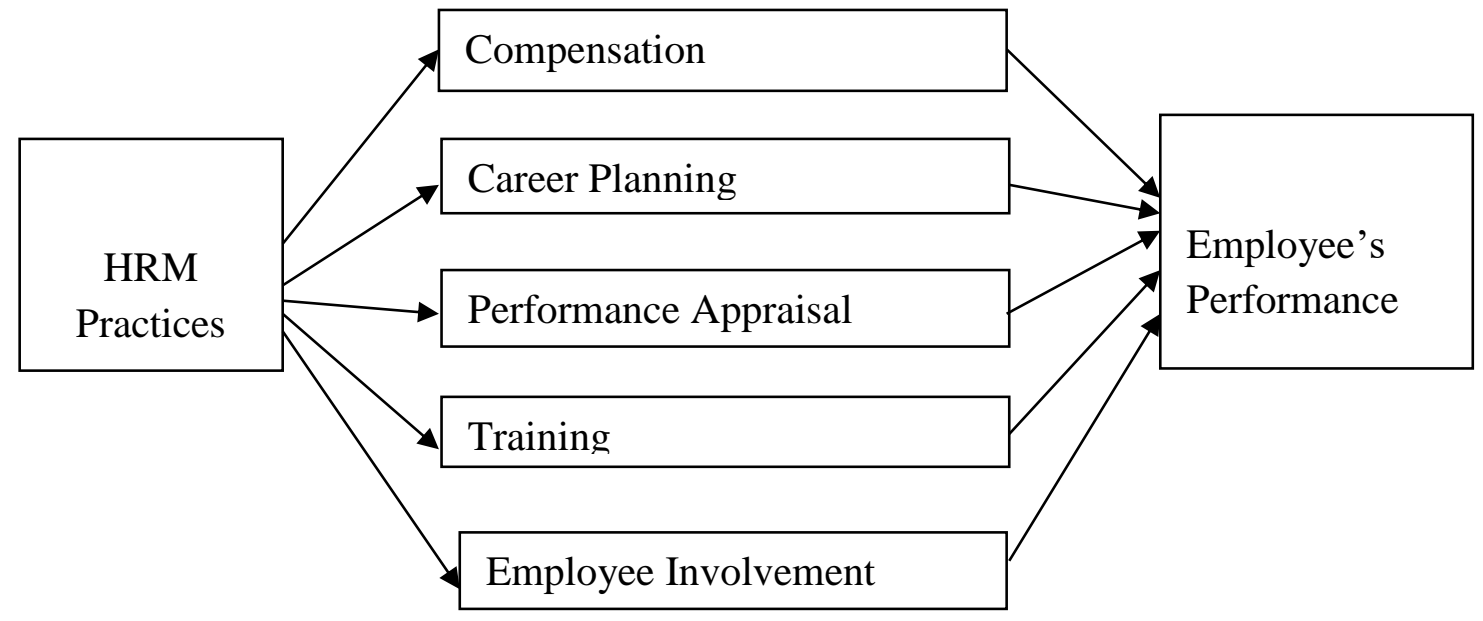

Figure 2 Impact of HRM Practices on Employee's Performance Source: Hassan (2016)

Based on the previous literature, the conceptual framework is built on the followings; 


\section{Conceptual Framework}

\section{Independent Variables Dependent Variable}

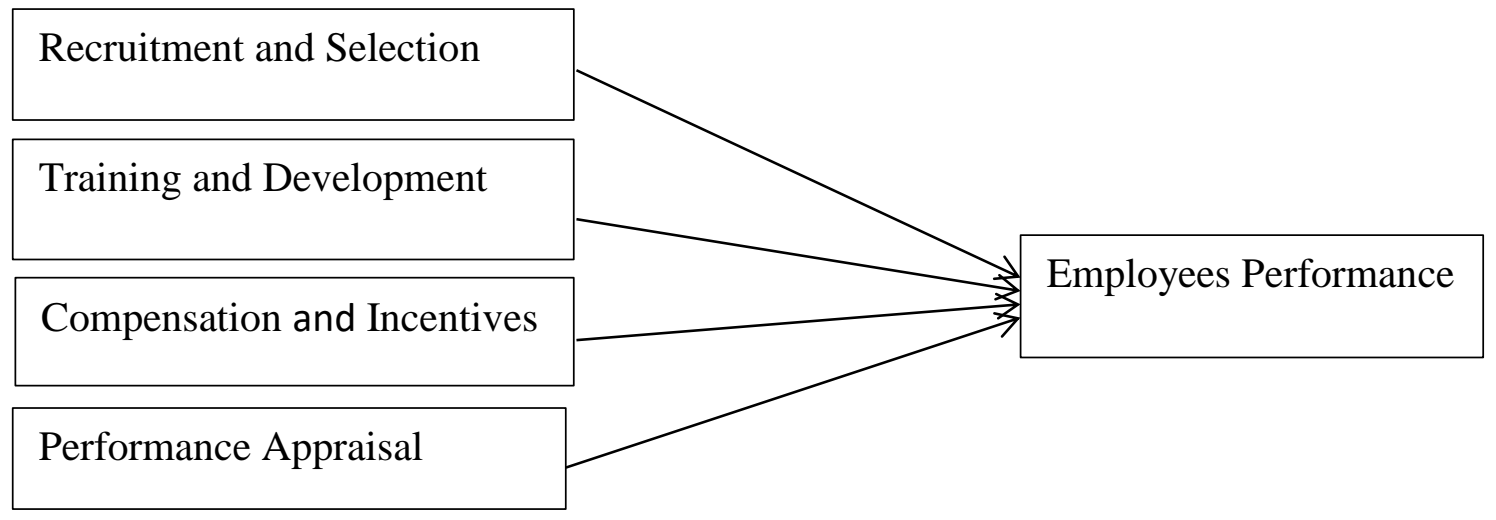

Figure 3: Conceptual Framework of the Study

Source: Author

\section{Research Methodology}

The study only focus on the effect of HRM practices on employees' performance at private banks. The rationale to choose the head office of three private banks such as Kanbawza bamk (KBZ bank), Ayeyarwady bank (AYA bank) and Co-operative bank (CB bank) behind this study is that these banks are more getting market shares than other the private banks. The populations were about managerial level 100 and non-managerial level 200 at KBZ bank, managerial level 80 and non-managerial level 150 at AYA bank and managerial level 80 and non-managerial level 140 at CB bank. This study applied two stage sampling method. At the first stage, three private banks such as KBZ, AYA and CB among many private banks by using simple random sampling method. At the second stage, the study used proportional method. A sample was selected by $20 \%$ of total population. . Primary data is collected for the purpose of study and addressing the problem. Therefore, the main source of getting data for this study is mainly from primary source.

Table 1 Level of the Respondents of Three Private Banks

\begin{tabular}{cccc}
\hline Banks & Position & Population & Sample (\%) \\
\hline KBZ & Managerial Level & 100 & 20 \\
& Non-Managerial Level & 200 & 40 \\
AYA & Managerial Level & 80 & 16 \\
& Non-Managerial Level & 150 & 30 \\
CB & Managerial Level & 80 & 16 \\
& Non-Managerial Level & 140 & 28 \\
\hline Total & & & 150 \\
\hline
\end{tabular}




\section{Questionnaires Design}

Questionnaires were used for the collection of primary data from the selected employees in the chosen private banks. The questionnaire consists of two sections which are section A and section B. Section A contains questions on demographic profile. The objective of demographic question was to acquire some basic information of the respondents. The questions include respondent's gender, age, marital status, highest education completed, current job experience, and job title. For Section B, the questions are based on dependent variable and independent variables are formed. The independent variables are recruitment and selection, training and development, compensation and incentives, and performance appraisals and dependent variables is employee performance.

Table 2 Measurement of Variable

\begin{tabular}{|c|c|c|c|c|}
\hline Variables & Category & Measurement & Measure & Expected Effect \\
\hline Recruitment and & Independent & - Recruitment system is & -6 items & Positive effect on \\
\hline Selection & Variable & $\begin{array}{l}\text { unbiased and systematic } \\
\text { process used for selection } \\
\text { employees. }\end{array}$ & $\begin{array}{l}-5 \text { point Likert } \\
\text { Scale }\end{array}$ & $\begin{array}{l}\text { Employee } \\
\text { Performance }\end{array}$ \\
\hline Training and & Independent & -Introduction of training and & -7 items & Positive effect on \\
\hline Development & Variable & $\begin{array}{l}\text { development programs for } \\
\text { employees. }\end{array}$ & $\begin{array}{l}-5 \text { point Likert } \\
\text { Scale }\end{array}$ & $\begin{array}{l}\text { Employee } \\
\text { Performance }\end{array}$ \\
\hline $\begin{array}{l}\text { Compensation and } \\
\text { Incentives }\end{array}$ & $\begin{array}{l}\text { Independent } \\
\text { Variable }\end{array}$ & $\begin{array}{l}\text {-Total reward received by an } \\
\text { employee in exchange for their } \\
\text { performance to the } \\
\text { banks.(Direct pay and indirect } \\
\text { pay or benefit). }\end{array}$ & $\begin{array}{l}-6 \text { items } \\
-5 \text { point Likert } \\
\text { Scale }\end{array}$ & $\begin{array}{l}\text { Positive effect on } \\
\text { Employee } \\
\text { Performance }\end{array}$ \\
\hline $\begin{array}{l}\text { Performance } \\
\text { Appraisals }\end{array}$ & $\begin{array}{l}\text { Independent } \\
\text { Variable }\end{array}$ & $\begin{array}{l}\text {-Motivate for employees in } \\
\text { working environment }\end{array}$ & $\begin{array}{l}-6 \text { items } \\
-5 \text { point Likert } \\
\text { Scale }\end{array}$ & $\begin{array}{l}\text { Positive effect on } \\
\text { Employee } \\
\text { Performance }\end{array}$ \\
\hline $\begin{array}{l}\text { Employees } \\
\text { Performance }\end{array}$ & $\begin{array}{l}\text { Dependent } \\
\text { Variable }\end{array}$ & $\begin{array}{l}\text { - To understanding how } \\
\text { employees are developing } \\
\text { professionally and how } \\
\text { contributing to work. }\end{array}$ & $\begin{array}{l}-9 \text { items } \\
-5 \text { point Likert } \\
\text { Scale }\end{array}$ & $\begin{array}{l}\text { Improved service } \\
\text { quality }\end{array}$ \\
\hline
\end{tabular}

Source: Author

\section{Analysis and Findings}

Table 3 shows the demographic characteristics of the respondents for HRM practices on employees' performance of Banking Industry. Number of female workers is larger than male workers in gender. Next, age levels are classified into four groups. Majority of the respondents comprises age group of 21 and 30. Position level for junior staff level is greater than from other levels. Moreover, income level in working industry is between 40001 and $60000 \mathrm{MMK}$ and working experience level is 1 to 5 years is more than from other levels. 
Borneo Journal of Social Science \& Humanities

DOI: https://doi.org/10.35370/bjssh.2021.3.1-04

e-ISSN:2682-8235

(c) 2018, UCTS Publisher.

Submitted: 16 May 2021

Accepted: 24 June 2021

Published: 30 June 2021

Table 3 Demographic Characteristics of the Respondents

\begin{tabular}{cccc}
\hline Demographic variable & Category & Number of Respondents & Percentage (\%) \\
\hline Gender & Male & 50 & 33.33 \\
& Female & 100 & 66.67 \\
\hline Marital Status & Single & 70 & 46.67 \\
& Married & 80 & 53.33 \\
\hline Age(Years) & $21-30$ & 60 & 60 \\
& $31-40$ & 40 & 40 \\
& $41-50$ & 40 & $40 \%$ \\
& Above 50 years & 10 & $10 \%$ \\
\hline Position & Manager & 15 & $10 \%$ \\
& Supervisor & 20 & 13.33 \\
& Senior Staff & 42 & 28 \\
& Junior Staff & 48 & 32 \\
& Securities & 25 & 16.67 \\
\hline Income & $100001-200000$ & 15 & 10 \\
& $200001-400000$ & 46 & 30.67 \\
& $40001-600000$ & 54 & 36 \\
& Above 600000 & 35 & 23.33 \\
\hline Working Experience & $1-5$ & 90 & 60 \\
& $6-10$ & 40 & 10 \\
& $11-15$ & 15 & $3.33 \%$ \\
\hline
\end{tabular}

Source: Author

Table 3 shows the demographic information of the respondents. The results show that out total 150 employees of private bank which including male respondents $(33.33 \%)$ and female respondents $(66.67 \%)$. Age of respondents are divided into five groups which are between 20 and 30 years old (60\%), between 31 and 40 years old (40\%), between 41 to 60 years old (40\%) and, above 50 years old (10\%). The positions of workers are manager (10\%), Supervisor (13.33\%), Senior Staff (28\%), and Securities (16.67\%). The respondents income level is as follows: between 100,000 - 200,00 MMK (10\%), 200,001 - 400,000 MMK (30.67\%), 400001 - 600000 MMK (36\%), and above $600000 \mathrm{MMK}(23.33 \%)$. The survey includes the employees who have working experience 1-5 years which accounts for $60 \%$, follows by 6-10 years (26.67\%), and 11-15 years $(10 \%)$, while the employees who have working experience more than $15 y e a r s$ merely account for $3.33 \%$.

Table 4 Analysis of Employee Perception on Recruitment and Selection of Private Banks

\begin{tabular}{|c|c|c|c|c|}
\hline Sr. No & Recruitment and Selection & Mean & $\begin{array}{c}\text { Std. } \\
\text { Deviation }\end{array}$ & $\begin{array}{c}\text { Level of } \\
\text { Agreement }\end{array}$ \\
\hline 1 & The company recruitment is fair. & 4.46 & 0.500 & Strongly Agree \\
\hline 2 & The company selection process is unbiased. & 4.46 & 0.500 & Strongly Agree \\
\hline 3 & $\begin{array}{l}\text { Applicants are fully informal about the } \\
\text { responsibilities and duties of the job. }\end{array}$ & 4.41 & 0.626 & Strongly Agree \\
\hline 4 & Recruitment and selection practices are systematic. & 3.99 & 0.901 & Agree \\
\hline 5 & The company attracts high quality employees. & 4.03 & 0.823 & Agree \\
\hline
\end{tabular}


Borneo Journal of Social Science \& Humanities

DOI: https://doi.org/10.35370/bjssh.2021.3.1-04

e-ISSN:2682-8235

(C) 2018, UCTS Publisher.

Submitted: 16 May 2021 Accepted: 24 June 2021

Published: 30 June 2021

6

Skilled and talented people are chosen for the

3.99

0.901

Agree

vacant job

4.2507

0.55475

Strongly Agree

Source: Author

Overall

According to the table 4, the statement of "the company recruitment is fair" and "the company selection process is unbiased" have the highest mean score 4.46. The statement of "Recruitment and selection practices are systematic" and "Skilled and talented people are chosen for the vacant job" have the lowest mean score 3.99. The overall mean of the employee perception on Recruitment and Selection of respondents is relatively high (greater than 3.5) It can conclude that they are very good at Recruitment and Selection practice.

\begin{tabular}{|c|c|c|c|c|}
\hline Sr. No & Training and Development & Mean & $\begin{array}{c}\text { Std. } \\
\text { Deviation }\end{array}$ & $\begin{array}{c}\text { Level of } \\
\text { Agreement }\end{array}$ \\
\hline 1 & $\begin{array}{l}\text { Banks adopt continuous training to improve } \\
\text { performance }\end{array}$ & 4.13 & 0.726 & Agree \\
\hline 2 & $\begin{array}{l}\text { Banks use new approaches for training } \\
\text { programs }\end{array}$ & 4.22 & 0.542 & Strongly Agree \\
\hline 3 & Banks encourage team-work seminars. & 4.31 & 0.615 & Strongly Agree \\
\hline 4 & $\begin{array}{l}\text { Banks are concerned about the quality of } \\
\text { training. }\end{array}$ & 4.19 & 0.708 & Agree \\
\hline 5 & $\begin{array}{l}\text { Training needs assessment is important for } \\
\text { training \& development program. }\end{array}$ & 4.07 & 0.808 & Agree \\
\hline 6 & $\begin{array}{l}\text { I can increase my competency level after } \\
\text { having training. }\end{array}$ & 4.13 & 0.720 & Agree \\
\hline \multirow[t]{2}{*}{7} & $\begin{array}{l}\text { Skill development support to reduce my time } \\
\text { consuming. }\end{array}$ & 4.33 & 0.596 & Strongly Agree \\
\hline & Overall & 4.1962 & 0.53798 & Agree \\
\hline
\end{tabular}

Source: Author

According to the table 5, the statement of "Skill development support to reduce my time consuming" has the highest mean score 4.33. The statement of "Training needs assessment is important for training \& development program" has the lowest mean score 4.07. The overall mean of the employee perception on training and development of respondents is relatively high (greater than 3.5). The findings conclude that the selected banks are effective in implementing the Training and Development practice.

\begin{tabular}{|c|c|c|c|c|}
\hline Sr. No & Compensation and Incentives & Mean & $\begin{array}{c}\text { Std. } \\
\text { Deviation }\end{array}$ & $\begin{array}{c}\text { Level of } \\
\text { Agreement }\end{array}$ \\
\hline 1 & $\begin{array}{l}\text { I received compensation leaves for working } \\
\text { overtime and IT payments as well. }\end{array}$ & 4.35 & 0.520 & Strongly Agree \\
\hline 2 & $\begin{array}{l}\text { Employees receive bonus depending on their } \\
\text { performance. }\end{array}$ & 4.36 & 0.495 & Strongly Agree \\
\hline 3. & $\begin{array}{l}\text { Employees are appreciated and recognized for } \\
\text { good work performance. }\end{array}$ & 4.37 & 0.485 & Strongly Agree \\
\hline
\end{tabular}


Borneo Journal of Social Science \& Humanities

DOI: https://doi.org/10.35370/bjssh.2021.3.1-04

e-ISSN:2682-8235

(C) 2018, UCTS Publisher.

Submitted: 16 May 2021

Accepted: 24 June 2021

Published: 30 June 2021

\begin{tabular}{llccc}
\hline 4 & $\begin{array}{l}\text { The company provides employees with the type } \\
\text { of benefits they need. }\end{array}$ & 4.25 & 0.477 & Strongly Agree \\
5 & $\begin{array}{l}\text { The company uses compensation programs based } \\
\text { on performance. }\end{array}$ & 4.53 & 0.501 & Strongly Agree \\
6 & $\begin{array}{l}\text { The company's compensation system is one of } \\
\text { the reasons to retain my job at the said company. } \\
\text { Overall }\end{array}$ & 4.39 & 0.528 & Strongly Agree \\
& 4.2707 & 0.52489 & Strongly Agree \\
\hline
\end{tabular}

Source: Author

According to the Table 6, the statement of "The company uses compensation programs based on performance has the highest mean score 4.53 and the statement of "The company provides employees with the type of benefits they need has the lowest mean score 4.25. The overall mean of the employee perception on Compensation and Benefit of respondents is relatively high (greater than 3.5). The findings conclude that the organizations are efficient at Compensation and Benefit practice.

Table 7 Analysis of Employee Perception on Performance Appraisal of Private Banks

\begin{tabular}{llccc}
\hline Sr. No & \multicolumn{1}{c}{ Performance Appraisal } & Mean & $\begin{array}{c}\text { Std. } \\
\text { Deviation }\end{array}$ & $\begin{array}{c}\text { Level of } \\
\text { Agreement }\end{array}$ \\
\hline 1 & $\begin{array}{l}\text { The performance appraisal is fair. } \\
\text { Employees receive a formal evaluation of their } \\
\text { performance. }\end{array}$ & 4.03 & 0.823 & $\begin{array}{c}\text { Agree } \\
\text { Strongly Agree }\end{array}$ \\
3. & $\begin{array}{l}\text { My performance evaluation depends on working } \\
\text { effectively and efficiently. }\end{array}$ & 4.19 & 0.501 & Agree \\
4 & $\begin{array}{l}\text { The company supports employees' development. } \\
\text { The company has realistic expectations about } \\
5\end{array}$ & 3.99 & 0.901 & Agree \\
6 & $\begin{array}{l}\text { employees' output. } \\
\text { The company provides feedback to employees'. }\end{array}$ & 4.41 & 0.651 & Strongly Agree \\
& Overall & 4.3756 & 0.37749 & $\begin{array}{l}\text { Strongly Agree } \\
\text { Strongly Agree }\end{array}$ \\
\hline
\end{tabular}

Source: Author

According to the Table 7, the statement of the "Employees receive a formal evaluation of their performance" has the highest mean score 4.51 and the statement of ". The company supports employees' development has the lowest mean score 3.99. The overall mean of the employee perception on performance appraisal of respondents is relatively high (greater than 3.5). The finding conclude that they are very good at performance appraisal practice.

Table 8 Analysis of Employee Perception on Employee Performance of Private Banks

\begin{tabular}{llccc}
\hline Sr. No & \multicolumn{1}{c}{ Performance Appraisal } & Mean & $\begin{array}{c}\text { Std. } \\
\text { Deviation }\end{array}$ & $\begin{array}{c}\text { Level of } \\
\text { Agreement }\end{array}$ \\
\hline 1 & $\begin{array}{l}\text { Job description is clearly spelt out for an employee } \\
\text { who improves on their performance. }\end{array}$ & 4.07 & 0.808 & Agree \\
2 & $\begin{array}{l}\text { I can increase my competency level after having } \\
\text { training. }\end{array}$ & 4.13 & 0.720 & Agree \\
$3 . \quad \begin{array}{l}\text { I can handle any problem after having training and } \\
\text { development programme. }\end{array}$ & 4.31 & 0.615 & Strongly Agree \\
4 & $\begin{array}{l}\text { I can reduce my absenteeism rate after having } \\
\text { training. }\end{array}$ & 4.13 & 0.720 & Agree \\
\hline
\end{tabular}


Borneo Journal of Social Science \& Humanities

DOI: https://doi.org/10.35370/bjssh.2021.3.1-04

e-ISSN:2682-8235

(c) 2018, UCTS Publisher.

Submitted: 16 May 2021

Accepted: 24 June 2021

Published: 30 June 2021

\begin{tabular}{llccc}
\hline 5 & $\begin{array}{l}\text { All level of employees' selection criteria is same for } \\
\text { their positions. }\end{array}$ & 4.22 & 0.542 & Strongly Agree \\
6 & $\begin{array}{l}\text { Performance appraisal makes motivate for } \\
\text { employee in working environment. }\end{array}$ & 4.33 & 0.596 & Agree \\
7 & $\begin{array}{l}\text { The compensation focuses on the employees from all } \\
\text { the levels of private banks' employee. }\end{array}$ & 4.29 & 0.608 & Strongly Agree \\
8 & $\begin{array}{l}\text { The compensation which is offered impacts the } \\
\text { employee's high performance. }\end{array}$ & 4.46 & 0.563 & Strongly Agree \\
9 & $\begin{array}{l}\text { Performance appraisal results are effect on } \\
\text { promotion. } \\
\text { Overall }\end{array}$ & 4.19 & 0.708 & Agree \\
\hline
\end{tabular}

Source: Author

According to the Table 8, the statement of the "The compensation which is offered impacts the employee's high performance has the highest mean 4.46, and the statement of "Job description is clearly spelt out for an employee who improves on their performance" has the lowest mean 4.07. The overall mean of the employee perception on performance appraisal of respondents is relatively high (greater than 3.5). The findings conclude that they are very good at performance appraisal practice.

Table 9 Reliability and Validity Test

\begin{tabular}{lcccc}
\hline \multicolumn{1}{c}{ Factors } & $\begin{array}{c}\text { No. of } \\
\text { Items }\end{array}$ & $\begin{array}{c}\text { Items } \\
\text { Retained }\end{array}$ & $\begin{array}{c}\text { Cronbach's } \\
\text { Alpha }\end{array}$ & $\begin{array}{c}\text { Validity } \\
\text { KMO }\end{array}$ \\
\hline Recruitment and Selection & 6 & 5 & 0.850 & 0.830 \\
Training and Development & 7 & 7 & 0.901 & 0.895 \\
Performance Appraisal & 6 & 5 & 0.852 & 0.856 \\
Compensation and Rewards & 6 & 6 & 0.847 & 0.858 \\
Employee Performance & 9 & 9 & 0.919 & 0.903 \\
\hline
\end{tabular}

Source: Author

According to Table 9, reliability test (Cronbach's Alpha value) of HR Practices factors such as recruitment and selection, training and development, performance appraisal, and compensation and rewards are more than 0.8 , while employee performance as well has value higher than 0.8. All KMO value are greater than 0.8. Thus, the patterns of correlation are relatively compact and the factor analysis will yield distinct and reliable factors. Bartlett's test is highly significant $(\mathrm{p}<0.001)$, and therefore, factor analysis is appropriate. 
Borneo Journal of Social Science \& Humanities

DOI: https://doi.org/10.35370/bjssh.2021.3.1-04

e-ISSN:2682-8235

(C) 2018, UCTS Publisher.

Submitted: 16 May 2021

Accepted: 24 June 2021

Published: 30 June 2021

Table 10 Analysis of the Effect of HRM Practices on Employee Performance

\begin{tabular}{|c|c|c|c|c|c|}
\hline \multirow{2}{*}{ Independent Variable } & \multicolumn{2}{|c|}{ Unstandardized Coefficients } & \multirow{2}{*}{$\mathbf{t}$} & \multirow{2}{*}{ Sig } & \multirow{2}{*}{ VIF } \\
\hline & B & SE & & & \\
\hline (Constant) & .152 & .079 & 1.926 & .056 & \\
\hline Recruitment and Selection & -.018 & .025 & -.741 & .460 & 4.911 \\
\hline Training and Development & .927 & .019 & 49.904 & .000 & 2.619 \\
\hline Performance Appraisals & .035 & .026 & 1.357 & .177 & 4.803 \\
\hline Compensation and Rewards & .028 & .019 & 1.452 & .149 & 1.369 \\
\hline $\mathrm{R}^{2}$ & & 0.979 & & & \\
\hline Adjusted $\mathrm{R}^{2}$ & & 0.978 & & & \\
\hline F statistics & & $1689.113^{* * *} *$ & & & \\
\hline
\end{tabular}

Dependent Variable: Employees Performance

Statistically significant indicate ***at $1 \%, * *$ at $5 \%, *$ at $10 \%$ level respectively

Source: Author

Table 10 indicated that $\mathrm{T}$ calculated value is 49.904 and significant value is $(0.000)$ which is less than $(\alpha \leq 0.05)$ which means that there is an effect of HRM practices on employees' performance. In addition the value of coefficient of Determination $\left(\mathrm{R}^{2}\right)$ is 0.978 which indicate that $(97.8 \%)$ of variance in employee performance through training and development. The other variables are not significance.

\section{Findings and Discussions}

As this study adopts the human resource management practices theory, the conclusion is made based on four categories namely recruitment and selection, training and development, performance appraisal, and compensation and incentives. The main objective of this study is to analyze the effectiveness of HR Practices on employee performance of the selected private banks in Yangon, Myanmar. The respondents consist of 150 employees of the selected private banks who worked in the head offices of each private bank. The questionnaires with five-point Likert scale items were used to collect the primary data and the constructs was developed based on previous literature. The respondents are improving performance with all level of agreement as "agree" of HR Practices and employee performance of selected banks namely AYA bank, KBZ, and CB in Yangon.

After analysing the collected data, the results show that the highest mean scores among the human resource practices elements are recruitment and selection, performance appraisal, and compensation and incentives. On the contrary, the lowest mean scores are training and development. However, multiple regressions analysis of effect of human resource management practices elements (recruitment and selection, training and development, performance appraisal, and compensation and incentives) on employee performance, training and development has positive relationship on employee performance.

The discussion of this study, the outcome results are compared with the similar studies and researches. the conclusion of this study is that human resource management practices is important factor to employee performance because it helps them to adapt better and faster changes that are rapidly occurring and leads to improving employee performance. The reasons of human resource 
management practices are to be ensuring that the skill level of employee is sustainable. According to these effects, the following section discusses the result of each objective.

To answer first research objective, the results reveal that HRMPs of the selected private banks in the study are examined using variables i.e., recruitment and selection, training and development, performance appraisal, and compensation and rewards. When analyzing the recruitment and selection of selected private banks, employees are uncertain whether the applicants are fully informed about the responsibilities, tasks and required qualifications, competences, and experience during the recruitment. According to the analysis of training schedule of banks' employees, the largest percent of training schedule is annually basis and the lowest percent of training schedule is other training schedule such as base on the situation of banks policy, procedures, and practices. Moreover, employees are satisfied with the materials provided in training program such as training facilities and equipment, trainers, food and amenity, time duration, and training location. For trainers, the majority of employees are preferred to be trained by professionals.

Referring to second objective, selected private banks are used the same performance appraisal method base on their training and development program results and customer feedback of service. Most of the private banks' labor turnover rate and performance is based on compensation and incentives. The compensation and incentives system are different across the selected private banks such as bonus system. It is concluded that HRM practices can improve the level of performance of the employee as it influences the employees' perception on bank's performance.

Moreover, according to regression analysis the value of the $\mathrm{F}$ test, the overall significance of the model, is highly significant at $1 \%$ level. According to the result, HRMPs elements (recruitment and selection, training and development, performance appraisal, and compensation and rewards) were strongly influencing performance of employees. Athar (2014) reported that there is a strong relationship of human resource practices and employee performance. Hassan (2016) as well mentioned the impact of human resource practices on employee performance. AlQudah et al., (2014) also proved that recruitment and selection and compensation affect performance of employees.

Furthermore, human resource management practices elements (recruitment and selection, training and development, performance appraisal, and compensation and rewards) are positively related to employee performance. The findings of the multiple regressions analysis indicated three variables in human resource management practices i.e., training and development and compensation and rewards have positive effects on employees' performance. In this study, training and developments is identified as the most significant IV in influencing banks employees' performance. As the results, employees of private banks feel that the training and development can improve speed and productivity in processing work, and thus, generally make less mistakes, and be more productive. It is concluded that HRM practices can enhance the employee's level of performance which influence the perception of employees about performance (Al-Qudah et al., 2014). 


\section{Conclusion and Recommendations}

The purpose of this study is to explore the impact of HRMPs on employee performance at the head office of private banks in Yangon and to suggest recommendations for its improvement. The findings of current research study illustrates that the HRMPs, especially training and development are positively related to employees' performance. Employees are one of the critical strategic assets for any organization. Likewise, banks should strive to attract the talent, well trained and enthusiastic employees and improve their performance. Successful and good effective implementation of HRMPs empowers bank's employees and improves their performance positively. Therefore, best practices of HRM stimulate bank staffs' performance which in turn improves HRM practices. The other HRMPs such as Recruitment and Selection, Reward management and performance appraisal are not significantly related. To increase its employee's performance, the bank management team should implement the successful and good effective implementation of training programs in order to increase their efficiency on the bank performance. To improve training program, Top management need to 5 steps to creating effective training programs such as Assess training needs, set organizational training. This result can be applied to other banking industry context only. Thus, future studies should consider a larger sample and other organizations.

\section{Reference}

Aguinis, H. \& Kraiger, K. (2009), Benefits of training and development for individuals and teams, organizations, and society. Annual Review of Psychology, 60, 451-474.

Al-Qudah, M. A., Al-Jaber, H. I., Zarga, M. H. A., \& Orabi, S. T. A. (2014). Flavonoid and phenolic compounds from Salvia palaestina L. growing wild in Jordan and their antioxidant activities. Phytochemistry, 99, 115-120.

Al-Qudah, H. M. A., Osman, A., \& Al-Qudah, H. E. M. (2014). The effect of human resources management practices on employee performance. International Journal of Scientific \& Technology Research, 3(9), 129-134.

Arthur, D. (2008), The First-time Manager's Guide to Performance Appraisals. New York: AMACOM, American Management Association.

Athar, W., Umair, B., Muhammad, Fahad, S., Hafiz, M. A., Imtiaz, H., Waqas, A., Muhammad, A. A., \& Rizwan, A. (2014). Factor influencing job satisfaction and its impact on job loyalty. International Journal of Learning \& Development, 4(2), 141-161.

Boudreau, J. W. \& Rynes, S. L. (1985). Role of recruitment in staffing utility analysis. Journal of applied psychology, 70(2), 354.

Bowra, Z. A., Sharif, B., Saeed, A., \& Niazi, M. K. (2012). Impact of human resource practices on employee perceived performance in banking sector of Pakistan. African Journal of Business Management, 6(1), 323-332.

Brown, M. E., Treviño, L. K., \& Harrison, D. A. (2005). Ethical leadership: A social learning perspective for construct development and testing. Organizational behavior and human decision processes, 97(2), 117-134. 
Borneo Journal of Social Science \& Humanities

DOI: https://doi.org/10.35370/bjssh.2021.3.1-04

e-ISSN:2682-8235

(c) 2018, UCTS Publisher.

Submitted: 16 May 2021

Accepted: 24 June 2021

Published: 30 June 2021

Carlson, D.S., Upton, N., \& Seaman, S. (2006). The impact of human resource practices and compensation design on performance: An analysis of family-owned SMEs. Journal of Small Business Management, 44(4), 531-543.

Chang, W.J. \& Huang, T. (2005), Relationship between strategic human resource management and firm performance: A contingency perspective. International Journal of Manpower, 26(5), 434-449.

Cook, C. W. \& Hunsaker, P. L. (2001). Management and organizational behavior. $3^{\text {rd }}$ Ed, New York: Irwin McGraw-Hill.

Cumming, M.W. (1993). The Theory and Practice of Personnel Management. London, Heinemann: William Heinemann Ltd.

Danish, R. Q. \& Usman, A. (2010). Impact of Reward and Recognition on Job Satisfaction and Motivation: An Empirical Study from Pakistan. International Journal of Business \& Management, 5(2), 159-167.

Danish, R.Q. \& Usman, A. (2010). Impact of reward and recognition on job satisfaction and motivation: An empirical study from Pakistan. International Journal of Business and Management, 5(2), 159-168.

Deb, T. (2006). Strategic Approach to Human Resource Management. Atlantic Publishers \& Dist.

Ganesan, S. (2014). Introduction of HRM. International Journal of Business and Administration Research Review, 1(6), 1-33.

Hassan, S. (2016). Impact of HRM practices on employee's performance. International Journal of Academic Research in Accounting, Finance and Management Sciences, 6(1), 15-22.

Hausdorf, P.A. \& Duncan, D. (2004). Firm size and internet recruiting in Canada: A preliminary investigation. Journal of Small Business Management, 42(3), 325-334.

Huang, D. Y. \& Nel, A. (2008). New 'Grylloblattida'related to the genus Prosepididontus Handlirsch, 1920 in the Middle Jurassic of China (Insecta: Geinitziidae). Alcheringa, 32(4), 395-403.

Jackson, S. E. \& Schuler, R. S. (2005). Managing individual performance: a strategic perspective. Psychology Management of Individual Performance, 371-390.

Jain, N.C. \& Saakshi, J. (2005). Textbook of Personnel Management and Human Resources. New Delhi: AITBS Publishers.

Kramer, O. \& Briffault, R. (1991). Workers Compensation: Strengthening the Social Compact. New York: University Press of America.

Mahmood, F., Iqbal, N., \& Sahu, S. R. (2014). The impact of human resource management practices on employee performance in banking industry of Pakistan. Euro-Asian Journal of Economics and Finance, 2(1), 86-99.

Mathis, R.L. \& Jackson, J. (2008), Human Resource Management. 13th ed. OH, USA: Cengage Learning.

Nel, P. S., Werner, A., Du Plessis, A. J., Fazey, M., Erwee, R., Pillay, S., Mckinnon, B., Millet, B., \& Wordsworth, R. (2012). Human Resource Management. Cape Town: Oxford University Press.

Pablos, P.O.D. \& Lytras, M.D. (2008). Competencies and human resource management: Implications for organizational competitive advantage. Journal of Knowledge Management, 12(6), 48-55. 
Roberts, G. E. (2002). Employee performance appraisal system participation: A technique that works. Public Personnel Management, 31(3), 333-342.

Salas, E., Tannenbaum, S.I., Kraiger, K., \& Smith-Jentsch, K.A. (2012). The science of training and development in organizations: What matters in practice? Psychological Science in the Public Interest, 13(2), 74-101.

Shen, J. \& Edwards, V. (2004). Recruitment and selection in Chinese MNEs. The International Journal of Human Resource Management, 15(4-5), 814-835.

Soomro, R.B., Gilal, R.G., \& Jatoi, M.M. (2011). Examining the impact of human resources management (HRM) practices on employees' performance a case study of Pakistani commercial banking sector. Interdisciplinary Journal of Contemporary Research in Business, 3(1), 865.

Tubre, T. C. \& Collins, J. M. (2000). Jackson and Schuler (1985) revisited: A meta-analysis of the relationships between role ambiguity, role conflict, and job performance. Journal of management, 26(1), 155-169.

Wood, S. \& Wall, T. (2002). Human Resource Management and Business Performance. In P. Warr (Ed.), Psychology at Work. 351-374. Penguin Press.

Zulfqar, S., Wahid, A., Farooq, M., Maqbool, N., \& Arfan, M. (2012). Phytoremediation of soil cadmium using Chenopodium species. Pak. J. Agri. Sci, 49(4), 435-445. 